\title{
Snell-Hornby, Mary: The Turns of Translation Studies: New Paradigms or Shifting Viewpoints? Benjamins Translation Library Vol. 66. Amsterdam/Philadelphia: John Benjamins, 2006. 205 pp. ISBN 9027216746.
}

In the preface to her new book, Mary Snell-Hornby, professor of translation studies at the university of Vienna (Austria), and former president of the European Society for Translation Studies, explains that rather than revise her book Translation Studies: An Integrated Approach (1988, 1995) for a third edition, she preferred to write an entirely new book. This new work is intended as a continuation of the earlier book in that it takes up issues discussed there and traces recent developments of the discipline up to and including the first years of the new millennium. The book is addressed mainly to students and teachers of translation studies, but because its presentation is clear and readable, it is accessible to anyone interested in language and intercultural communication.

The book is organized chronologically, with one chapter devoted first to the "great precursors" (Schleiermacher, Goethe, von Humboldt) and the "immediate precursors" of the $20^{\text {th }}$ century (in particular Roman Jakobson, Jiři Levý, Vinay and Darbelnet, Eugene Nida). Special emphasis is placed on the contributions of Otto Kade and Fritz Paepcke. The first chapter also introduces the pragmatic turn in linguistics in the 1970s, which was to have an important effect on how texts were studied, and acknowledges the role of James S. Holmes as a "central pioneer".

The "turns" of the title are the new directions taken in translation studies in the 1980s and later. Chapter 2 deals with the cultural turn of the 1980s, first covering the role of the so-called Manipulation School and the emergence of Descriptive Translation Studies. The scholars whose work is presented in this chapter include such luminaries as Gideon Toury, André Lefevere, Theo Hermans and Susan Bassnett. Instead of gauging the equivalence of a translation to its source text, these scholars tended to reject the concept and to view translations descriptively and from the target cultural point of view. Another development at the same time, in Germany, was the rise of the skopos theory, initiated by Hans J. Vermeer in the late 1970s and adopted with enthusiasm at first in German translation studies (Katharina Reiss, Hans Hönig, Paul Kussmaul). In the skopos theory, too, the role of the target culture, its norms and conventions, was seen to be central. Out of this grew an emphasis on the translator's professional role as evidenced by the work of Justa Holz-Mänttäri: translators do not simply engage in decoding and recoding but need to be aware of the client's requirements and to be responsible for producing texts that fulfil their expected function in the real world. 
Chapters 3 and 4 attempt to cover the main developments in the 1990s, when the work of the masters of the previous decade inspired that of a legion of followers. Snell-Hornby wisely sets as her aim here to focus on the most innovative or far-reaching of the new ideas and concepts; she also helpfully tries to unravel some problems of terminology resulting from the same terms (for example function and norm) being used in slightly different senses by scholars representing different approaches. This part of the book will be especially useful for teachers and students of translation studies. The functional model of translation critique (constructed by Ammann, 1990, and presented on pp. 109-114) could be applied to both literary and non-literary texts and would give thesis writers engaged in analysing source texts and their translations useful tools to work with. Chapter 3 also touches on translation of multimedial texts (such as subtitling), of postcolonial literature and of feminist translation studies.

Chapter 4 deals first with the empirical turn (including think-aloud protocols made during the translation process as well as study on mono- and bi- or multilingual electronic corpora) and then the globalization turn. Globalization here refers to translation in technology, business and other international discourse, with discussion of the increasing dominance of English and the hybridity of some intercultural or supracultural communication. The author largely (and wisely) bypasses detailed presentation of technological advances in translating as any state-of-the-art description would be outdated after a few years. Both for teaching purposes and for general readers there are a number of amusing - or chilling - examples of intercultural communication gone wrong. One described advertisement went so badly wrong that the firm that had commissioned it would not allow the ad to be reproduced in the book.

Chapter 5 is where Snell-Hornby is most polemical, addressing some of her fears for the future of translation studies. She thinks that scholars are not always very clear about what has been discussed in the discipline earlier, and so the wheel gets reinvented with some regularity. Equivalence, for example, while discredited in the 1980s yet tends to be reintroduced by scholars who do not attempt to take account of earlier arguments against it. The author also has reservations about the growth of interest recently among some translation scholars in a more linguistically oriented approach, which she sees as retrogression.

The final "turn" in the book is the turn of the millennium (chapter 6): SnellHornby does not quite accept as new the ideological and sociological turns that have been proposed for the $21^{\text {st }}$ century. She is also concerned about the low status of translators and of translation studies and urges translation scholars to try to amend the situation by producing work that is both innovative and relevant to society and doing so in a clear and jargon-free style. 
The Turns of Translation Studies will be read in every university department where translation studies has a place but it deserves to be read more widely. Because it looks for the larger perspective, it is accessible to language professionals in all spheres of life. The circa five hundred references to work in six languages and the three hundred items in the subject index make the work all the more useful.

\section{References}

Ammann, Margret. 1990: “Anmerkungen zu einer Theorie der Übersetzungskritik und ihrer praktischen Anwendung." TextConText 5. 209-250.

Snell-Hornby, Mary. 1988 ( $2^{\text {nd }}$ edition 1995): Translation Studies: An Integrated Approach. Amsterdam: John Benjamins.

Ritva Leppihalme 
